\title{
Die problematiek rondom "gebedsgenesing" en die "genadegawes van genesing" soos wat dit in die pinksterbeweging geleer en beoefen word
}

\author{
G C VELTHUYSEN
}

Die bedoeling van hierdie artikel is tweërlei. In die eerste plek is dit 'n poging om kortliks ' $n$ aanduiding te gee van die leerstellings wat rondom die saak van "gebedsgenesing" en die "genadegawes van gesondmaking", binne die geledere van die pinkstergesindes in swang is. Daarnaas is dit ' $n$ poging tot beoordeling van gemelde standpunte, en 'n verantwoording van die kerk se standpunt in hierdie verband.

Dit is ' $n$ geweldig ingewikkelde en uitgebreide probleemveld, uiteindelik word dit haas onoorsigtelik. Probleme wat opduik en vrae wat vra om beantwoording is onder andere die volgende: Vanwaar kom siekte? Is dit van God of van die duiwel? Is dit 'n "kwaad" of 'n "goed"? Is dit straf of seën? Hoe moet ons die genesingswonders van Christus en die apostels verstaan? Is die genadegawes van genesing bedoel as 'n ewige gawe aan die kerk? Wat is die verhouding tussen gebed en genesing; tussen geloof en genesing? Hierdie reeks vrae kan vermenigvuldig word en dan sal die antwoorde weer nuwe vrae oproep.

Hierdie artikel wil nie 'n uitputtende analise of behandeling van die hele probleemveld wees nie. Dit is ' $n$ poging om die essensie van dit waarom dit gaan, raak te vat.

\section{Enkele inleidende opmerkings}

Naas die glossolalie en die profesie, is die genadegawes van gesondmaking (I Kor 12:9), die geestesgawe wat die meeste aandag van die pinkstergesindes ontvang. Dit wil egter nie sê dat daar onder hierdie mense enige mate van eenstemmigheid is oor die vraag wat presies onder "genadegawes van gesondmaking" verstaan moet word nie. Trouens, wanneer mens die beskikbare literatuur uit dié kringe bestudeer, tref dit jou dat hulle self besig is om met hierdie saak te worstel. Een van die leidinggewende figure in die pinksterbeweging sê dan ook: "Terselfdertyd is die Pentekostaliste ook nog soekende na 
'n duidelike begrip van wat die genadegawes van gesondmaking presies beteken en hoe dit in die praktyk werk." (F P Möller, Die diskussie oor die charismata soos wat dit in die pinksterbeweging geleer en beoefen word, Evangelie Uitgewers, 1975, bls 219).

As basiese uitgangspunt geld egter die standpunt, dat hierdie geestesgawe nie opgehou het om te bestaan nie maar nog ten volle in die gemeente werksaam kan en moet wees. Die voorkoms van die gawe word aangedui as ' $n$ noodwendige manifestasie van die Heilige Gees. Die gevolgtrekking wat hulle dus uit hierdie standpunt maak is: Waar die Gees is, sal hierdie gawe in een of ander vorm werksaam wees; waar hierdie gawe egter nie funksioneer nie, kan die Gees ook nie wees nie.

Dit is belangrik om daarop te let dat hierdie mense ' $n$ onderskeid maak tussen twee tipes van genesing binne die raamwerk van die kerk. Hulle praat van: "Genadegawes van genesing" en "goddelike genesing". Laasgenoemde is dan 'n aanduiding van 'n genesing wat God direk werk (hetsy in antwoord op die gebed, hetsy onafhanklik van die gebed), sonder 'n menslike kanaal. By die genadegawes van gesondmaking is die menslike kanaal egter die primêre, want die begaafde mens ontvang volmag om die siekte te genees: "As 'n mens die genadegawe van gesondmaking vir'n sekere siekte ontvang het, beteken dit nie jy moet tot God bid vir genesing en dan wag om te sien of Hy dit geskenk het nie, maar dit is dan soos Harold Horton dit stel: "Heal the sick, says the Lord to His followers. Not, ask Me and I will heal them." (Möller, bls 222). By die charisma van genesing is dit dus, volgens hulle opvatting, die mens self wat handelend optree, begenadig deur die Heilige Gees. By goddelike genesing is dit 'n geval van: bid en wag op God.

In dié verband maak Möller 'n verbasende erkenning: "In die praktyk slaag die Pentakostaliste egter selde daarin om deur die genadegawes van gesondmaking genesing te weeg te bring; dit is maar meestal 'n gevral dat die Here gevra word om die sieke te genees en dan te wag en te hoop dat Hy dit sal doen" (bls 222). Dit kom baie naby aan ' $n$ erkenning dat hierdie genadegawe nie meer werksaam is nie. Maar daar word nogtans baie hard probeer om aan te toon presies hoe dit werksaam is, of werksaam behoort te wees.

Wat nou volg is ' $n$ poging om vanuit die toeganklike literatuur 'n beeld te skilder van wat hierdie mense dink en glo oor hierdie saak. Hieruit behoort hulle worsteling om begrip baie duidelik na vore te kom, asook die teologiese voorveronderstellings waarmee hulle werk.

\section{'n Weergawe van die beskouings}

'n Ondersoek van die standpunte lewer die volgende op: 
Siekte en sonde hou direk met mekaar verband. Siekte is 'n direkte gevolg van die sondeval en daarom 'n manifestasie van die werksaamheid van die duiwel. Jesus Christus kom oorwin die duiwel en verbreek die mag van die sonde. Dit beteken dat Hy ook al die manifestasies van die sonde oorwin en vernietig. Dit, op sy beurt, beteken dat Christus wil hê dat al sy kinders gesond moet wees. Dit is sy wil dat siekte van die aarde sal verdwyn.

Hy gee dan ook aan sy dissipels die mag om die siekte te oorwin. As bewysvoering hiervoor word die volgende teksverse aangehaal: Lukas 4:18-19; Matteus 10:5-15; Lukas 10:9; Markus 16:15-20; Johannes 14:12-13. Hierdie skrifgedeeltes word só uitgelê dat Jesus aan sy dissipels, daarna aan die ganse kerk en uiteindelik aan elke gelowige die bediening van die genesing geskenk het. Markus 16:18 word uitgelê as 'n ewige belofte wat hierdie krag aan elke gelowige toesê.

Hierdie bediening van genesing manifesteer homself op twee maniere: die institusionele en geinspireerde genesing:

\section{Institusionele genesing}

Hieronder verstaan hulle die handeling van die kerk, en dit word afgelei uit Jakobus 5:14-16. Dienaangaande word die volgende gestel:

Die voorwerp van die institusionele genesing van die kerk is die gelowiges;

dit word bedien deur die ouderlinge;

dit geskied deur middel van gebed en salwing met olie. (Hier is daar 'n groot verskil in opinie, maar talle skrywers, waaronder Aaron Linford, beskou dit as 'n sakrament. In sy werkie "Spiritual Gifts", stel hy dit só: "The oil is not used as a remedy, but as a sacrament");

die beginsel waarvolgens die genesing in hierdie geval bewerk word, is die "inwonende Gees" (vergelyk Romeime 8:11). Die gebed en salwing "bevry" as't ware hierdie Gees om die oorsaak van die siekte uit die weg te ruim. Die salwing met die olie is 'n teken en seël van die helende werking van die Gees;

die voorwaarde vir genesing is geloof en gebed. Linford stel dit dan ook so dat daar vir die sieke gebid moet word totdat hy gesond is. Dit maak nie saak hoe lank dit duur nie.

\section{Geinspireerde genesing}

Hieronder word genesing verstaan wat veroorsaak word deur die genadegawes van genesing. Die kenmerke hiervan is die volgende: 
Dit gebeur spontaan, onmiddellik en volkome;

dit word veral bedien aan die ongelowiges;

dit kan deur enige gelowige bedien word;

dit is 'n uitwendige krag, wat niks te maak het met die een wat die genesing ontvang nie - maar dit setel in die een wat die gawe ontvang het.

Die doel wat God het met die gee van hierdie gawe aan die gelowiges, word soos volg beskryf:

Om siekes te verlos en die mag van die Bose te verbreek; om Jesus se aanspraak dat Hy die Seun van God is te bevestig!; om die evangelie wat deur die Here se diensknegte verkondig word te bevestig;

om te bewys dat Jesus opgestaan het;

om mense te lok na die verkondiging van die Woord! (Johannes

6:2 word as bewysplaas aangehaal);

om mense na God te bekeer;

om eer en lof aan God te bring;

om Gods volk met geloof en moed te inspireer.

Wat die wese en inhoud van hierdie gawe betref, lees ons onder andere die volgende:

Dit is 'n "genadegawe" wat vryuit deur die Gees gegee word, sonder enige verdienste aan die kant van die ontvanger;

dit is 'n volmaakte gawe, in die sin dat dit volmaakte genesing bewerk, sonder die hulp van geneesmiddels of wat ookal;

dit is beperk sover as wat dit sy manifestasie betref. Die feit dat daar in die meervoud van "genadegawes" gepraat word, het allerhande wonderlike verklarings tot gevolg gehad. Die vernaamste hiervan is dat daar 'n genadegawe van gesondmaking vir elke soort siekte is. So kan een mens die gawe ontvang om borskwale te genees - terwyl ander weer meer sukses het met die genesing van buiksiektes; nog een kan kanker gesond maak en 'n ander weer hoë bloeddruk ensovoorts.

'n Ander uitleg is dat die meervoud op verskillende vorms van genesing wys. Dan word daar 'n verskil gemaak tussen evangelistiese genesing (Mark 16:17) en ekklesiastiese genesing (Jak 5:14).

Nog ' $n$ ander uitleg is dat die meervoud aandui dat elke afsonderlike genesing 'n genadegawe van God is, wat ontvang en oorgedra word deur die kanaal wat deur die Heilige Gees verkies word. Voorstanders van hierdie uitleg sien hierin die verklaring, waarom baie mense wat die bediening van goddelike genesers opsoek, nie genees 
word nie. Hierdie genesers kan nie volgens willekeur genees nie. Hulle kan dit net oordra soos en wanneer hulle dit ontvang.

'n Laaste uitleg wat gegee word, is die wat verklaar dat die meervoud wys op genadegawes wat periodiek met die oog op die sending en evangelisasie gegee is; veral wanneer nuwe gebied ontgin is. Daarna verdwyn dié genadegawe dan en maak plek vir die vorm van genesing soos beskrywe in Jakobus 5 .

\section{Die bediening van die genesing}

Die bediening van die genesing binne die raamwerk van die Pentekostalisme neem een van twee vorms aan. Of dit geskied in die pastorale of gemeentelike bediening, of in die massasituasie. Laasgenoemde kan ook genoem word: die groot-tent situasie. Hierdie bediening, wat deur die sogenaamde evangeliste waargeneem word (waaronder Oral Roberts), vertoon ook sy eie teologiese onderbou.

\section{Die "groot-tent" situasie}

Die hiervolgende opvattings is tipies van hierdie soort bediening. (Alle aanhalings wat in hierdie gedeelte gebruik word, kom uit die boek van Möller.):

Alle siekte is van die duiwel afkomstig. Oral Roberts stel dit soos volg: "When Jesus healed the people of their sickness, spiritual, mental and physical, He was freeing them from die oppression of the devil. Sickness is not counted among the blessings of the Gospel but is counted the enemy of human life". (bls 226); naas die verdrukking deur die duiwel (hulle praat by voorkeur van "opressie"), word ook geleer dat siekte die gevolg kan wees van werklike duiwelbesetenheid. Oral Roberts sien byvoorbeeld in epilepsie en in alle vorms van seksuele afwyking, 'n openbaring van duiwelbesetendheid. Evangelis $M$ A Daoud verklaar: "Blind devils make people blind, deaf ones make people deaf etc., and cancer demons eat out the vital organs or wherever they fasten themselves" (bls 227);

daar word 'n duidelike verband gelê tussen saligheid en die genesing van die liggaam. Roberts stel dit só: "There cannot be a physical healing until a miracle has happened in your soul. God miraculously heals the spirit first. When we refuse Him that, we stop the flow of His healing power into our bodies" (bls 227); daar word ook sterk klem gelê op die feit dat God al die siekes wil genees. Christus het gekom om die mag van die duiwel te verbreek. Alle siektes is die werk van die duiwel, en daarom wil $\mathrm{Hy}$ alle siektes vernietig. In dié verband verklaar evangelis Os- 
borne: "Both body and spirit are brought back from Satan's jurisdiction. Both should glorify God. You do not glorify God in your spirit with sin, nor in your body with disease" (bls 228). Hierdie uitspraak, wat daarop neerkom dat 'n siek mens die Here nie kan loof nie, is miskien die onbarmhartigste waarvan ek weet;

hierdie mense glo dat elke mens 'n mate van geloof in God ontvang het. Deur die beoefening daarvan kan hy gesond word; elke belofte in die Bybel, en by name dan dié oor genesing, is bedoel vir elkeen wat dit lees: In die verband verklaar T L Osborne: "God's Word is always God speaking to you personally. You are healed because God said you were healed. Don't heed your senses. Give God's Word its place" (bls 228). Die pyn en die ongemak van die sieke mag wel nog bly voortbestaan, maar die simptome is slegs bewyse en getuienisse van jou sintuie. "We refuse to give in to what our senses tell us, because they are carnal. They are natural. Instead, we accept God's Word as true and act accordingly. As sure as God sits on the throne, He will make His Word good in us" (Osborne, aangehaal op bls 230).

'n Pragtig-vindingryke stukkie eksegese vind ons in 'n opmerking van Kenneth Hagin: "Do the things that you could not do before. If you could not bend over do so. If you could not walk before, start walking. God has committed Himself to honour your faith. If you could not see before, start looking. Faith, if it has not works (or action) is dead, being alone (James 2:17)."

Pastorale of gemeentelike bediening van die genesing

Hierdie bediening vertoon grootliks dieselfde teologiese onderbou; maar daar is tog aanduibare verskille:

Daar word gewoonlik in hierdie konteks nie beweer dat alle siekte van die duiwel kom nie. Hier verneem ons van vyf redes waarom'n mens siek kan word:

- Deur jouself, deurdat jy die natuurwette oortree.

- Deur ander, dit wil sê by wyse van aansteeklike siektes of aanrandings.

- Deur "chaotiese" omstandighede soos byvoorbeeld aardbewings, ongelukke ensovoorts.

- Deur Satan, alhoewel hy maar beperkte mag het.

- Deur God. (Naas goddelike genesing is daar ook iets soos goddelike siekte!) As bewysplaas vir laasgenoemde stelling, word II Konings 5:27 aangehaal;

- daar word ook nie geglo dat dit altyd die wil van God is om te genees nie, en hier en daar is 'n skrywer te vind wat nie 'n direkte verband tussen geloof en genesing lê nie. 


\section{Beoordeling}

Die belangrikste beswaar wat teen bogenoemde visies ingebring kan word, is die uiters onverantwoordelike gebruik van die Skrif. Die Bybel word heeltemal meganies benader en tekste word heeltemal uit verband geruk en op die klank af uitgelê. Sodoende word die Bybel gedwing om te "buikspreek", want met so'n Skrifgebruik kan mens die Bybel enigiets laat sê. Die gevolg hiervan is dat die hele teologiese onderbou, wat staatmaak op so'n Skrifgebruik, afgewys moet word.

Billikheidshalwe moet vermeld word dat daar uit die geledere van die Pentekostaliste self, harde stemme opgaan wat die meer absurde leerstellings afwys en verdoem. Uit die boek van Möller, waaruit ek al so dikwels aangehaal het, volg hier nou'n verkorte weergawe van sý kritiek teen die massagenesingsveldtogte:

- Die direkte verband wat daar tussen siekte en die werking van die duiwel gelê word, is nie Bybels te verantwoord nie;

- om blindheid, doofheid, epilepsie ensovoorts sondermeer as duiwelse magte in die mens te sien, is nie te verantwoord nie;

- die bewering dat dit God se wil is om elke siekte te genees, is foutief omdat dit op die verkeerde veronderstelling berus dat elke siekte deur die duiwel veroorsaak is;

- om te beweer dat mens God nie deur 'n siek liggaam kan dien nie, berus op ' $n$ verkeerde eksegese van I Korintiërs 6:20. Hierdie teks het te maak met hoerery en nie met krankheid nie;

- daar word, in die sogenaamde "bediening", gebruik gemaak van groepgees en massasuggestie. Dit gaan te veel om die sensasie en te min om die waarheid. Die meganiese wyse waarop Bybeltekste gebruik word, rangeer die Gees eintlik uit. Dit word uiteindelik niks anders nie as sielkundige en psigiese genesing.

Aldus dan Möller. Met hierdie kritiek is ons dit van harte eens. Maar daar moet bygevoeg word dat hierdie kritiek, alhoewel effens getemper, net so gerig kan word aan die adres van die geinstitueerde pinksterkerke. Want ten spyte van Möller se betoog tot die teendeel, leer die praktyd ons, dat dieselfde gedagtes en praktyke by hulle in swang is. Ons is almal bewus van die evangelisasie en genesingsveldtogte wat van tyd tot tyd in die naam van een van hierdie kerke gehou word. Wanneer dit gebeur, vertoon dit grotendeels dieselfde kenmerke as die wat deur Möller so radikaal afgewys word. Dit is in elk geval duidelik dat dieselfde Skrifgebruik is swang is, en dat daar gevolglik vanuit dieselfde teologiese voorveronderstellings gewerk word.

Ook hier geld daar as basiese uitgangspunt: Die verlossing in Christus is nie net ' $n$ verlossing uit die mag van die sonde nie; dit is 
verlossing uit die gevolge van die sonde. Siekte is ' $n$ direkte gevolg van die sonde, en daarom verlos Christus ons van die siekte. Deur die genadegawes van gesondmaking gee $\mathrm{Hy}$ dan aan die gelowiges die volmag om die siekte, in al sy verskyningsvorms, te oorwin en vernietig.

\section{'n Kort verantwoording van die standpunt van die kerk}

Hier volg kortliks 'n eie standpunt, deur die stel én beantwoording van 'n paar pertinente vrae.

Wat is die plek van siekte in die bestaanswerklikheid?

Dit is miskien die kernvraag wat beantwoord moet word. En onmiddellik is ons in 'n verleentheid. Die verleentheid is geleë in die feit dat daar nie 'n eensydige antwoord moontlik is op grond van die gegewens van die Bybel nie. Trouens, die Bybel vertoon, wat dit betref, ' $n$ veelkleurigheid. Aan die een kant is daar verwysings na gevalle waar siekte ervaar moet word as 'n straf en die gevolg van die sonde. Hier kan ons byvoorbeeld dink aan Gehasi, die dienskneg van Elisa (II Kon 5:27). Aan die ander kant van die skaal is daar die vermelding van siektetoestande, waar sonde en straf hoegenaamd nie in die spel kom nie. Hier kan ons dink aan die man wat blind gebore is (Joh 9:1 v v), want "die werke van God moet in hom geopenbaar word". Om dus reglynig 'n verband te lê tussen sonde en siekte, lyk nie verantwoordbaar nie.

Om die duiwel te sien as die bewerker van alle siekte, gaan ook nie op nie, want die Bybel getuig ook dat God die siekte as tugmiddel kan stuur (byvoorbeeld Amos 4:6-10). Om alle siekte egter terug te voer na God as die oorsaak en bewerker daarvan, kan ook nie, as ons erns maak van al die gegewens van die Bybel nie (vergelyk die geskiedenis van Job). ' $n$ Feit is dat 'n reglynige antwoord net nie moontlik is nie.

Omdat ' $n$ reglynige antwoord nie moontlik is nie, moet daar nie gepoog word om sodanige antwoord te fabriseer nie. Die kerk moet die moed van sy oortuiging hê, om te sê dat hy nie weet nie. Maar hierdie ontwykende kennis is in elk geval nie die belangrikste saak in die wêreld nie. Wat werklik belangrik is, is dat die gelowige wat siek word, moet vashou aan die Bybelse waarheid, dat God sy kinders nie verlaat nie; dat Hy siekte kan aanwend tot die eer van sy Naam en dat Hy alles ten goede laat meewerk vir hulle wat Hom liefhet. 
Watter betekenis moet geheg word aan die genesingswonders van die Nuwe Testament?

Die feit dat Christus en die apostels siekes genees het, kan nie weggedink of weggeredeneer word nie. Maar terwyl dit waar is, is dit ewe waar dat dit hoogs onverantwoordelik is, om primêre betekenis aan hierdie wonders toe te skryf. Van primêre betekenis is die Woord en die verkondiging daarvan (Luk 10:41-42). Die genesingswonders, soos die ander wonders van Jesus, moet gesien word as begeleidende tekens (Luk 7:22). Sodanige tekens dien as 'n openbaring daarvan dat die koninkryk van God gekom het, en dat dit in die persoon van Jesus Christus gekom het. Nêrens is daar sprake daarvan dat Hy gekom het om te genees nie. Nêrens is daar sprake daarvan dat dit die sentrale waarheid van die evangelie is nie. Die standpunt van die genesingdwepers wek onvermydelik die indruk dat hulle dit só beskou.

Het die genadegawes van gesondmaking verdwyn of word dit nog deur die Gees geskenk?

Dat die Heilige Gees hierdie unieke gawe aan besondere mense geskenk het, blyk op grond van die Nuwe-Testamentiese getuienis bokant alle twyfel verhef. Vanuit die Handelinge van die apostels is baie voorbeelde bekend waar Petrus en die ander mense gesond gemaak het; dink maar byvoorbeeld aan die genesing van die kreupelgebore man, soos meegedeel in Handelinge 3. Die vraag is egter of die pinkstergesindes geregverdig is in hulle standpunt dat, waar hierdie en die ander "buitengewone" gawes van die Gees nie voorkom nie, daar ook nie sprake van kerk kan wees nie. Hulle standpunt kom in feite daarop neer dat hierdie buitengewone gawes die merkteken van die kerk word.

Dit is duidelik dat hierdie gawes in Korinte bekend was. Maar nêrens verhef Paulus dit tot merkteken van die kerk nie. Trouens, juis aan die Korintiërs stel hy dat die belangrikste merkteken in die bestaan van die gemeente, die liefde is en dan ook nie maar liefde in die algemene sin van die woord nie, maar liefde as 'n gawe van die Gees (1 Kor 13). Saam met die liefde noem hy dan die geloof en die hoop. Hierdie drie geestesgawes is die belangrikste en sentrale in die kerk van Christus. Ons is daarom geregverdig om te sê dat hulle, en niks anders nie, die merktekens van die kerk van Christus en die teenwoordigheid van die Gees is.

Maar beteken dit dat die gawes van gesondmaking nie meer bestaan of kán bestaan nie? Op grond van die Bybelse gegewens kan ' $n$ mens dit nie sê nie. Daar is wel nêrens 'n aanduiding dat hierdie gawes vir ewig aan die kerk gegee is nie; maar aan die ander kant is 
daar ook geen aanduiding dat dit net vir 'n tydlank gegee is nie. Wanneer 'n mens egter die getuienis van die kerkgeskiedenis naderroep, lyk dit baie waarskynlik dat ons die mening moet uitspreek dat hierdie gawe aan die vroeë kerk gegee is as 'n begeleidende teken, naas die verkondiging van die Woord. Die feit dat dit heel vroeg in die kerkgeskiedenis alweer verdwyn het, mag 'n aanduiding wees dat dit bedoel was vir die vestigingsjare van die kerk.

Dit wil egter nie sê dat hierdie genadegawe of charisma, nooit weer aan iemand gegee kan of sal word nie. Dit is ' $n$ saak wat in die hande van God is en waaroor ons nie 'n uitspraak kan maak nie. Maar om, soos die pinkstergesindes doen, hierdie gawe, op grond van die voorkoms daarvan in Korinte te verhef tot 'n voorwaarde vir kerkwees, is onverantwoordelik en onskriftuurlik.

Dit wil voorkom asof die kerk in hierdie opsig die volgende uitspraak moet maak: Die genadegawes van gesondmaking kan, as God dit so wil, nog in die kerk funksioneer. As Hy weer hierdie charisma aan die kerk wil gee, sal $\mathrm{Hy}$ dit doen. Maar die noodsaak daarvoor word nie deur die Bybel betuig nie. En ons aanvaar die Bybel as die geopenbaarde Woord van God. Hierdie gawe is in elk geval nie noodsaaklik vir die bestaan of voortbestaan van die kerk nie. Dit was tog mos nie die genesingswonders van die apostels wat die mense tot geloof gebing het nie maar die prediking van die evangelie van Jesus Christus (vergelyk Romeine 10:13-15; I Korintiërs 2:3-5 en talle ander plekke).

Is gesondheid of "gesondword" die hoogste goed?

Dit was die groot teoloog Karl Bahrt wat eenmaal gesê het dat gesondheid as sodanig nie die belangrikste is nie, maar wat jy daarvan en daarmee maak; hoe jy dit gebruik. Gebruik jy jou gesondheid en lewenskragte tot eer van God - dan is jou gesondheid 'n goed. Gebruik jy dit egter om die sonde te dien, is dit ' $n$ kwaad.

Net só kan siekte 'n goed wees. 'n Mens sou kon sê dat dit 'n seën kan wees. Wanneer siekte byvoorbeeld daarvoor sorgdra dat ' $n$ persoon weer met homself en met God in gesprek tree, weer met en by homself stilword, en voor God stilword, is dit 'n goed. Dan is dit iets waarvoor ons selfs dankbaar kan wees.

\section{Wat mag ons van God verwag?}

Nadat alles gesê is, bly die een groot waarheid staan: God is die groot Geneser. P J T Koekemoer is heeltemal reg as hy sê dat alle genesings gesien moet word as komend van God (Sektekenmerke, H A U M, 1973 , bls 58). Dit geld in laaste instansie ook van genesings wat bewerk word deur die chirug se mes of die toediening van allerlei medikamente. 
Maar afgesien van bogenoemde perspektief, moet die aandag ook gevestig word op 'n nog diepergrypende evangeliese waarheid. God is werklik nie net geinteresseerd in die gees van die mens nie, maar in die mens as geheel (anders gesê: die totale mens). Die liggaamlike lê nie buite die blikveld van die evangelie nie. Die Skriftuurlike getuienis hiervoor is so oorweldigend dat dit nie 'n verdere betoog nodig het nie. Ons hoef maar net te dink aan die bewoënheid van Jesus oor die siekes en armes, of die optrede van die apostels, veral soos betuig in die eerste hoofstukke van die Handelinge, om te besef dat die evangelie nie uitsluitend op die gees van die mens gerig is nie. Die heil van Christus raak die mens ook in sy liggaamlikheid. Dit gaan weliswaar nie nét en selfs nie oorwegend om die liggaamlikheid nie, maar tog óók daaroor.

Nou het die vraag by my opgekom, of die oorwoekering van die liggamlike by die aanhangers van die "genesingsveldtogte", nie dalk die skuld van die kerke is nie. Die vraag is of daar nie'n te eensydige klem gelê is op die geestelike van die mens nie. Die vraag kan ook anders geformuleer word: Is die kerke nie geneig om die volle heil, wat in Christus geskenk is, te "vereskatologiseer" nie? Word daar nie te min klem gelê op wat ons mag en kan verwag, en te veel klem op die feit dat ons maar moet berus in omstandighede nie? Is die "berustingsprediking" en "berustingspastoraat" nie somtyds 'n "sondige" berusting nie? Ek haal graag aan uit die werkie van $\mathrm{A}$ Heymans, "Geloofsgenezing" (Boekencentrum, s'Gravenhage, 1962, bls 37): "Als wij aan deze zondige berusting toegeven, vergeten wij dat God ons met Christus in een geheel andere orde gezet heeft, die zich verzet tegen de zichtbare orde, die ons buite Christus gevangen houdt, maar waaruit Christus ons bevrijdt tot een nieuw leven, dat zich met Hem verzet tegen die door de zonde gestoorde orde. Onze gehele houding tegen wat slecht en zwak en ziek is, zou veranderen, wanneer wij deze dingen op meer bijbelse wijze wilden verstaan. Want het is niet in woorden uit te drukken, wat de Heer doen kan aan wie op Hem hopen".

Wat mag ons van God verwag? Nie alles, soos ons by die genesingsdwepers aantref nie. Hulle wil die volle heil nou alreeds ervaar. Maar die volle heil sal eers ' $n$ werklikheid wees by die weerkoms van Christus. Maar ons mag iéts verwag. God se beloftes in Christus betref nie net die einde van die dae nie. Dit sê ook nou aan ons bepaalde dinge toe. Op grond van hierdie beloftes kan ons bid en hoop dat God ook aan ons genesing sal skenk.

Wat is die verhouding tussen gebed en genesing?

Daar is in elk geval nie ' $n$ meganiese verhouding nie. Die gebed is nie ' $n$ towerformule of magiese spreuk wat genesing kan bewerk nie. 
Dit is ook nie die geloof waarin of waarmee gebid word, wat genees nie. Dit is Hy op wie die geloof gerig is en tot wie gebid word wat kan genees. Die gebedsverhoring lê ook nie in die geloof van die een wat bid nie; al het die geloof daarmee te maak. Gebedsverhoring lê in die Een tot wie gebid word. Wat somtyds "geloofsgenesing" of "gebedsgenesing" genoem word, is ' $n$ antwoord van die Here op ons gebed, ' $n$ beseëling van die vertroue wat in Hom gestel is. Dit is dus 'n daad van die Here self. Dit is ook 'n saak van die Here self. Die beslissing lê uiteindelik by Hom. Dit beteken dat die gebed aangeneem, maar ook afgewys kan word.

Dit is duidelik dat die Here self aan die gebedsverhoring grense stel. Vanuit die Bybelse getuienis kan ons op Moses net maar die aandag vestig. Hy hoor van die Here dat $\mathrm{Hy}$ moet ophou om te vra om die beloofde land in te gaan, want God het anders besluit: "Dit is nou genoeg! Moenie nog verder met My oor hierdie saak spreek nie" (Deut 3:27). Verder dien gelet te word op die gebedsworsteling van Paulus. Ook hy word nie verhoor nie en kry van God die antwoord: "My genade is vir jou genoeg" (II Kor 12:9).

Maar bostaande mag ons nie laat vergeet dat die gebed van die gelowige groot krag het nie. Dit mag ons ook nie laat vergeet dat ons die uitnodiging van God het, om Hom eintlik lastig te val met ons gebede nie (Luk 18:1-8). Ons móét bid. Dit is werklik 'n bevel waaronder ons staan. Ons moet en mag vra. Ons moet net onthou dat die beslissing by Hom berus. Dit is, nadat alles gesê is, die waarheid waarom dit gaan.

\section{Afsluitend}

Die laaste twee sinnetjies van die vorige paragraaf, dui miskien die wesentlike verskilpunt tussen die kerk en die genesingsdwepers aan. Hulle aanvaar dat geloof en gebed enersyds, en die genadegawes van gesondmaking andersyds, op grond van ' $n$ toesegging deur God genesing sál bewerk; en dit dan op 'n heel meganiese wyse. Ons aanvaar dat dit ' $n$ verkeerde interpretasie van die Bybelse getuienis is. Ons aanvaar dat die Bybel leer dat God uiteindelik sal beslis, en dat ons daarom ons vertroue op Hom moet plaas en ook uiteindelik in sy beslissing moet berus.

Ons glo dat die genesingsdwepers, alhoewel dit natuurlik nie hulle bedoeling is nie, tog 'n uiters onbarmharige leer verkondig. Om die voorkoms en voortbestaan van siekte aan ongeloof te wyt, of reglynig as die resultaat van persoonlike sonde te sien, is 'n verduistering van die evangelie. Die troosvolle evangeliese waarheid in die verband, is dat dit tot die rykdom en vryheid van Christenwees behoort om siek te kan wees sonder ' $n$ verontruste gewete, en dat ons siekte ons nie 
kan skei van die liefde van God wat daar in Christus Jesus ons Here is nie (Rom 8:31-39).

\section{Geraadpleegde literatuur}

1. P J Theron: Gebed en genesing vir die Pastorale Sorg. Doktorale proefskrif 1969 , Pretoria.

2. P J T Koekemoer: Gebed-en-genesing-geloof-en-genesing Opgeneem in die bundel "Sektekenmerke", HAUM 1973, Pretoria.

3. F P Möller: Die diskussie oor die garismata soos wat dit in die Pinksterbeweging geleer en beoefen word. Evangelie Uitgewers, Braamfontein 1975.

4. A Hijmans: Geloofgenezing. Boekencentrum N V s'Gravenhage 1962.

5. Howard Carter: Questions and answers on Spiritual Gifts. Assemblies of God Publishing House, Nottingham.

6. Laurence J Erasmus: Die Heilige Gees en sy nege gawes. Sarepta Sending Pers, Kuilsrivier.

7. W G Hathaway: The Gifts of the Spirit in the Church. Elim Publications Board, Cheltenham, Glos, derde druk 1972.

8. Aaron Linford: Spiritual Gifts, Assemblies of God Publishing House, London.

9. P C Nelson: Bible Doctrines. Southwestern Press, Enid, Oklahoma.

10. W T H Richards: Divine Healing, Advance Press, Slough Bucks, England. 